\title{
CORRESPONDENCE
}

\section{Drift thickness maps of Scotland}

SIR,- - The first of a new series of transparent overlays showing variations in thickness of drift and, in some cases, in rock-head level is available from the Edinburgh Office of the Institute of Geological Sciences. The overlays, on the scale of 6 inches to 1 mile, are designed to be used with the appropriate geological or O.S. National Grid quartersheet. They show National Grid $1 \mathrm{~km}$ intersections and drift isopachytes at levels of $1,5,10,15,20,25,30,35$ and 40 metres, or rock-head contours at 5-metre intervals.

The programme is at present confined to the Edinburgh district and the IrvineKilmarnock area. Drift thickness overlays will shortly be available for 6 -inch quartersheets NT $27 \mathrm{NW}, 27 \mathrm{SW}$, and $27 \mathrm{SE}$, and both drift thickness and rock-head contour overlays will be available for NS $33 \mathrm{NW}, 33 \mathrm{NE}, 34 \mathrm{SW}$, and 34 SE. The drift thickness overlay for NT 27 NE (north-eastern Edinburgh) is available now. The intention is that the programme will be extended to cover, initially, adjacent sheets in both areas. Copies will be supplied to order at a cost each of $£ 1.35$ (Permatrace) or $£ 2.00$ (Ozalid Ozatype Clear Film); orders may be submitted for any of the 12 overlays listed above.

Although much of the information given by the overlays is dependent on the judgement and interpretative skill of the compiling geologist, and some of it is inevitably largely conjectural, it is based on a consideration of all the data available from surface observation, from boreholes, and from excavations. One of the reasons for the selection of these two areas for this project was the generally high density of relevant data there. The Edinburgh overlays are based on computer-produced maps which incorporate the findings of all the boreholes in the area, and these maps have been modified only where additional information and geological interpretation show them to be in error or highly unlikely to be correct.

Orders and requests for further information should be sent to

\section{The Assistant Director \\ Institute of Geological Sciences \\ 19 Grange Terrace \\ Edinburgh EH9 2LF}

Institute of Geological Sciences

Exhibition Road

SIR KINGSLEY DUNHAM

London SW7 2DE

12th September 1973

\section{A Mediterranean catastrophe?}

SIR,-Professor Sylvester-Bradley (1973) raised the question of the presence of a deepwater Atlantic fauna in Pliocene beds immediately above the Upper Miocene GessosaSolfifera formation of Sicily, as being the possible indicator of a catastrophe. The answer is really quite simple in terms of palaeo-oceanography.

The Mediterranean Sea has not always had a water deficit as it has today. In glacial times the Mediterranean Sea had a water surplus that translated itself into a surface current of lower-density waters flowing out through the Straits of Gibraltar and a bottom current flowing in. Huang et al. (1972) found sedimentological evidence in the Alboran Sea that some 9000-11000 years B.P., at the end of Würm glaciation, a current reversal took place. This reversal occurred in a geologically brief period without catastrophic consequences.

Geol. Mag. 111 (1), 1974, pp. 79-86. Printed in Great Britain. 